\title{
Seroepidemiological Survey of Canine Leishmania Infections from Peripheral Areas in Natal, Northeast Brazil
}

\author{
Isabelle Ribeiro Barbosa ${ }^{\mathrm{a}, \mathrm{c}}$, Francisco Canindé Carlota ${ }^{\mathrm{a}}$ and Valter Ferreira de Andrade-Neto, ${ }^{\mathrm{b},{ }^{*}}$
}

${ }^{a}$ Centro de Controle de Zoonoses, Departamento de Vigilância à Saúde, Secretaria Municipal de Saúde. Natal/RN, Brazil

${ }^{b}$ Departamento de Microbiologia e Parasitologia, Centro de Biociências, Universidade Federal do Rio Grande do Norte, Campus Universitário, Av Senador Salgado Filho Sn, Lagoa Nova, CEP 59078-970 - Natal/RN, Brazil

${ }^{c}$ Programa de Pós-Graduação em Ciências Biológicas, Universidade Federal do Rio Grande do Norte, Campus Universitário, Av Senador Salgado Filho Sn, Lagoa Nova, CEP 59078-970 - Natal/RN, Brazil

\begin{abstract}
Background and Objective: Human visceral leishmaniasis is endemic in Natal, northeast of Brazil, where the domestic dog is an important parasite reservoir in the infectious cycle of Leishmania spp. In this study, was evaluated the antileishmanial IgG antibody and epidemiological factors related to canine visceral leishmaniasis (CVL).

Methods: Sera samples obtained by venipuncture of 1,426 dogs living in areas of human visceral leishmaniasis occurrence were tested for detection of IgG anti-leishmania antibodies with Immunofluorescence Antibody Assay (IFA) and Enzyme Linked Immunosorbent Assay (ELISA). Chi-square $\left(\mathrm{x}^{2}\right)$ and Odds Ratio (OR) were calculated. Differences were considered statistically significant at $p \leq 0.05$.

Results: The overall seroprevalence was $10.30 \%(147 / 1,426)$; prevalence increased when the samples were found to be positive at least for one technique $([417 / 1,426] 29.3 \%)$. The high percentage of seroprevalence was observed in Nova República (15.35\%), Nova Natal I (12.7\%) and Lagoa Azul (11.4\%) neighborhoods. In the Planalto, Soledade and Brasil Novo, the infection rates ranged from 7.5 at $8.06 \%$. $(p=0.00051)$. There was neither statistically significant difference between leishmanial infection nor clinical signs of disease $(p=0.84 ; \mathrm{OR}=1.0[0.41 ; 2.3])$, sex $(p=0.78, \mathrm{OR}=0.94[0.66$; $1.28])$; and breed $(p=0.92 ; \mathrm{OR}=1.0[0.65 ; 1.54])$ were observed.

Conclusion: The results suggest that CVL is widely distributed in Natal, may be increasingly urbanizing and will spread through neighborhoods but not endemic, resulting in a serious public health problem, emphasizing the need for epidemiological studies to a greater understanding of the distribution of canine leishmaniasis in these specific areas and contribute proactively to the public health policies.
\end{abstract}

Keywords: Canine visceral leishmaniasis, ELISA assay, Epidemiology, IFA assay.

\section{INTRODUCTION}

Visceral leishmaniasis (VL), caused by Leishmania (Leishmania) chagasi in Brazil, is a zoonotic disease and the domestic dog is the main reservoir of human infection, and phlebotomine sand flies are the biological vectors of this parasitosis. In Brazil, this disease remains a major challenge in public health issues, through adaptation of Leishmania vectors to periurban areas and their spread to new areas in many Brazilian states, mainly in the northeastern states [1, 2]. The increasing geographic dispersion of VL is a serious

*Address correspondence to this author at the VFAN at Departamento de Microbiologia e Parasitologia, Centro de Biociências, Universidade Federal do Rio Grande do Norte, Campus Universitário, Av Senador Salgado Filho Sn, Lagoa Nova, CEP 59078-970 - Natal/RN, Brazil;

Tel: +55 84 3215-3437; Ext: 225; Fax: +55 84 3211-9210;

E-mail: aneto@cb.ufrn.br public health problem with more than 70,000 cases in the last decades and a high mortality [3]. In Natal, capital of Rio Grande do Norte, during the first quarter of 201334 cases of human VL were reported [4].

In Brazil, the disease is widespread, being transmitted by the bite of sandflies, and Lutzomyia longipalpis is the main species involved [5]. Dogs are implicated as the most important reservoirs of the disease in zoonotic form [6], being responsible for maintaining the parasite in endemic areas, where there is a high prevalence of parasitic forms in these animals due to the presence of amastigotes in the skin, and its proximity to the man.

For this reason, one of the strategic targets for disease control is considered [7], mainly because the majority of seropositive dogs do not show clinical signs, acting as potential reservoirs, and being an important key link in the 
Table 1. Seroprevalence of visceral leishmaniasis in domestic dogs in peripheral areas of Natal, Rio Grande do Norte state, Brazil.

\begin{tabular}{|c|c|c|c|}
\hline Localities & Total Samples & Reactive Samples (IFA/ELISA) & Seroprevalence CVL (\%) \\
\hline \hline BRASIL NOVO & 248 & 13 & $8.06 \%$ \\
\hline LAGOA AZUL & 35 & 04 & $11.4 \%$ \\
\hline NOVA NATAL & 346 & 46 & $12.7 \%$ \\
\hline NOVA REPUBLICA & 293 & 45 & $75.35 \%$ \\
\hline PLANALTO & 280 & 21 & $7.5 \%$ \\
\hline SOLEDADE & 224 & 18 & $7.6 \%$ \\
\hline TOTAL & 1426 & 147 & $10.3 \%$ \\
\hline$p=0,00051 ;$ IFA: Indirect Immunofluorescence Assay; ELISA: Enzyme Linked Imunosorbent Assay; CVL: Canine Visceral Leishmaniasis
\end{tabular}

transmission chain of VL [8]. In addition, the role of humans and canines with asymptomatic disease infection has not been fully elucidated within the chain of Leishmania transmission, and more studies are needed to better evaluate the impact of silent infection in maintaining endemicity [9]. Thus, the success of strategies for VL control which generally occurs in poverty and in underdeveloped areas, basically depends on situational knowledge of disease transmission dynamic, considered in control programs as an essential condition, and the canine serological survey achievement which is used for this. Thus, the aim of this study was to determine the frequency of Canine Visceral Leishmaniasis (CVL) in poverty areas of the municipality of Natal, Rio Grande do Norte, correlating canine infection with factors as breed, sex and symptoms of canine infection, thus, contributing to public policy in Health.

\section{MATERIALS AND METHODS}

The study was conducted in Natal (latitude $5^{\circ} 47^{\prime} 42^{\prime \prime}$ e longitude $\left.35^{\circ} 12^{\prime} 34^{\prime \prime}\right)$, capital of Rio Grande do Norte state, located in the eastern coastal region of the state, at an altitude of $30 \mathrm{~m}$, with an area of $169.9 \mathrm{~km}^{2}$. It is limited with the municipalities of the São Gonçalo do Amarante (west), Extremoz (northward), Parnamirim (south) and Atlantic Ocean (east). Natal city has about 806.203 inhabitants [10], distributed in four (04) administrative regions: North, Nouth, East and West; which comprise a total number of 36 neighborhoods with territorial, physical, demographic and infrastructure differences. It has an average annual temperature of $28^{\circ} \mathrm{C}$, annual rainfall mean of $1,554.3 \mathrm{~mm}$, with the range of months from February to August those of higher precipitation andrelative humidity of $75 \%$ [11].

This is a descriptive epidemiological study conducted with secondary data obtained from reports of Leishmaniasis Control Programme, of the Zoonosis Control Center in Natal, and data from human Leishmaniasis cases were obtained from the Information System for Notifiable Diseases (SINAN), the Municipal Health Service of Natal City.

In this study, during one year, 1,426 blood samples from pet dogs in Lagoa Azul, Nova Natal, Brasil Novo, Nova república, Soledade and Planalto neighborhoods were collected. The serological survey was conducted in pet dogs with around an area $300 \mathrm{~m}^{2}$ of human case occurrences of visceral leishmaniasis. Blood samples $(5 \mathrm{ml})$ were collected without anticoagulant and centrifuged; sera obtained were kept stored frozen until use $\left(-20^{\circ} \mathrm{C}\right)$. The information on gender, breed and symptoms from dogs were noted by file card Visceral Leishmaniasis control program.

Indirect Immunofluorescence Assay and Enzyme Linked Imunosorbent Assay (Bio-Manguinhos/FIOCRUZ Kit) for canine visceral leishmaniasis were used for the diagnosis of canine infection. For the statistical analysis Epi Info 3.5 and the chi-square $\left(\mathrm{x}^{2}\right)$ and odds ratio were calculated, and differences were considered statistically significant when $\mathrm{p} \leq$ 0.05 . The seroprevalence of canine infection with gender, breed and clinical symptoms were compared to evaluate differences between the frequency in different localities studied.

\section{RESULTS}

In a canine serological survey 1,426 canine blood samples were analyzed. 147/1,426 (10.3\%) samples were found to be positive for CVL. Considering that canine infection positivity is demonstrated by at least one of the serological techniques (IFA and / or ELISA), the prevalence increased was $19 \%$ (ranging from $10.30 \%$ up to $29.3 \%$ ) (Fig. 1).

The highest seroprevalence was observed in Nova República (15.35\%), followed by Nova Natal (12.7\%) and Lagoa Azul (11.4 \%) neighborhoods. The lower seroprevalence was observed in Planalto, Brazil Novo and Soledade, with infection rates ranging between 7.5 and $8.06 \%$. Thus, the prevalence of CVL has different distributions in the localities studied $(p=0.00051)$ (Table 1). Regarding gender of the 147 positive dogs, $54.4 \%$ were female and $45.6 \%$ were male $(\mathrm{p}=0.78$, OR $=0.94[0.66$; $1.28]) ; 78.2 \%$ were mongrel dogs and $21.9 \%$ were breed $\operatorname{dogs}(p=0.92 ; O R=1.0[0.65 ; 1.54]$ and $95 \%$ of those infected showed no clinical signs of disease $(\mathrm{p}=0.84$; OR $=$ $1.0[0.41 ; 2.32]$. Therefore, sex, breed and symptoms were not associated with IgG antibodies anti-Leishmania (Table 2).

\section{DISCUSSION}

The seroprevalence results of this study differ from findings from Amóra et al. [12] and Torres \& Brandão Filho 


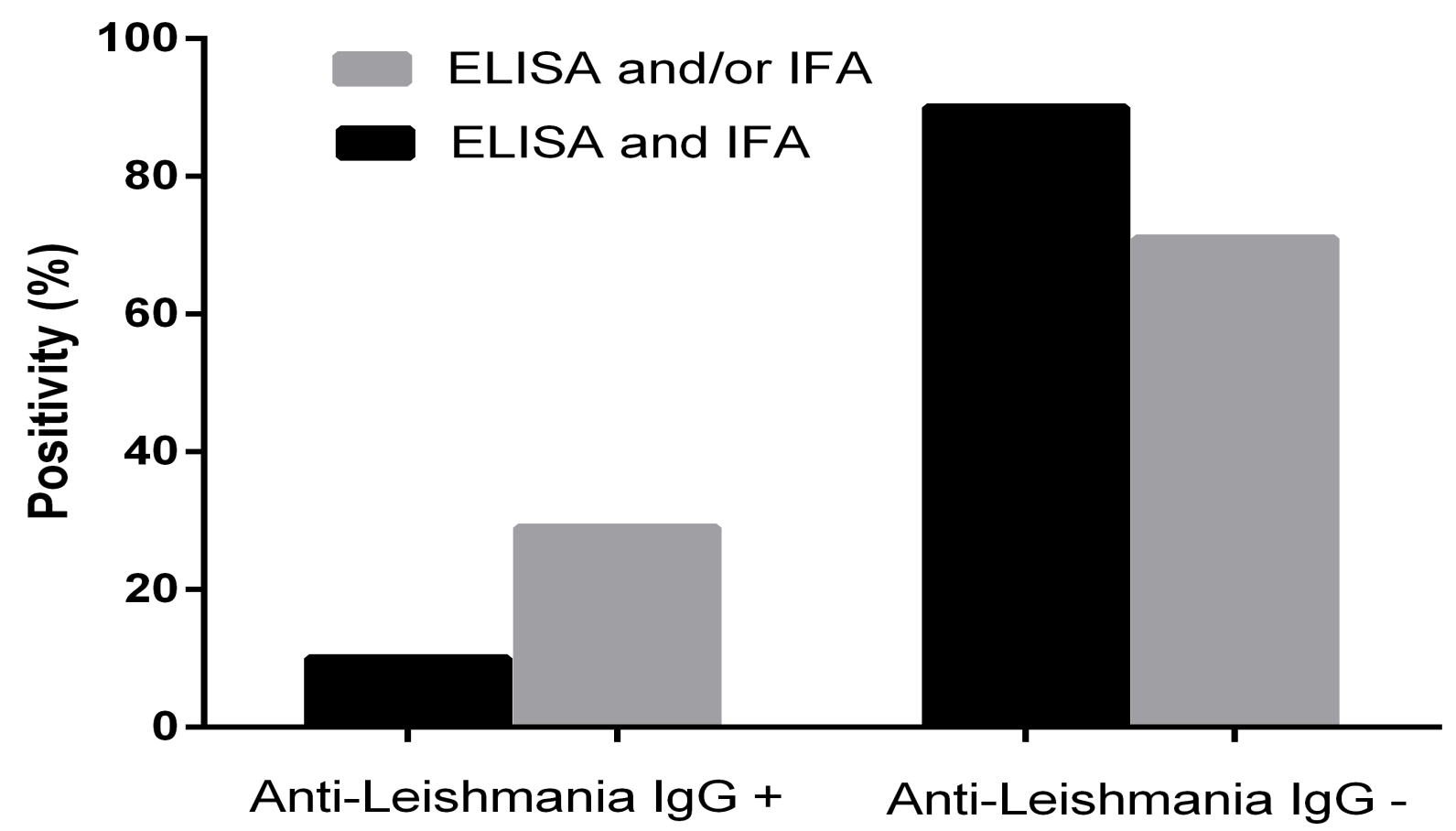

Fig. (1). Serological survey conducted for Visceral Leishmaniasis in domestic dogs in the city of Natal, considering the positivity of the techniques used in one or both techniques (ELISA / IFA).

Table 2. Seroprevalence of visceral leishmaniasis in dogs related to gender, breed and presence of characteristic symptoms, Natal, Rio Grande do Norte state, Brazil.

\begin{tabular}{|c|c|c|c|c|c|}
\hline & Factors & IFA/ELISA Reactive n (\%) & No- Reactive n (\%) & Odds Ratio (IC) & $p$-value \\
\hline \multirow{2}{*}{$\operatorname{sex}$} & Male & $80(54.4 \%)$ & $716(56 \%)$ & $0.94[0.66 ; 1.28]$ & 0.78 \\
\hline & Female & $67(45.6 \%)$ & $563(44 \%)$ & & \\
\hline \multirow{2}{*}{ breed } & Mongrel dogs & $115(78.2 \%)$ & $1001(78.2 \%)$ & $1.0[0.65 ; 1.54]$ & 0.92 \\
\hline & Breed dogs & $32(21.8 \%)$ & $278(21.7)$ & & \\
\hline \multirow{2}{*}{ characteristic symptoms } & Presence* & $07(4.7 \%)$ & $61(4.7 \%)$ & $1.0[0.41 ; 2.32]$ & 0.84 \\
\hline & absence & $140(95.2 \%)$ & $1218(95.2 \%)$ & & \\
\hline
\end{tabular}

* hair loss, weight loss, skin sores, apathy, nails grown, the occurrence of at least one of these symptoms already characterized as symptomatic dog.

[13], which showed $55 \%$ seropositivity rate using the same serologic test in dogs in Mossoró city, Rio Grande do Norte state, in 2002; and $1.6 \%$ in Paulista city, Pernambuco state, respectively. In this work, the results differ from the study carried out by Silva et al. [14], which showed that the canine seroprevalence was $25.0 \%$. Similarly, the researches conducted in Portugal [15] and Brazil [16] showed the prevalence ranged from 20.4 to $26 \%$, however, they remain consistent with other results in Brazil and in other countries [17-20]. Since the 70s, has been observing the urbanization phenomenon of Visceral Leishmaniasis has been observed [21]. The environmental changes such as prolonged and periodic droughts, followed by migration, urbanization and rural exodus, have caused the expansion of endemic areas and the new outbreaks emergence of the disease. These factors lead to a reduction in the ecological space of this parasitosis, facilitating epidemic occurrence.

The main determinants of the current endemic levels of VL are interconnected in complex epidemiological networks. Among all, we highlighted the existence of inadequate agricultural practices, irrational soil exploration, interruption of epidemiological surveillance process, disorderly urbanization of forest areas, and the presence of infected canids, favoring urban adaptation of Leishmania parasite [22]. In Natal, is found a characteristic and appropriate environment to occurrence of new Leishmaniasis 
transmission foci. The habitations are mostly poor, disabled in garbage collection and sanitation, in some areas, many residents have a precarious socioeconomicus status, and contact with domestic animals is high, providing favorable conditions for the occurrence of disease transmission. It is important to note that other risk factors for VL are perhaps more complex, as the urbanization of the transmission cycle and maintenance of an enzootic cycle in the city [23]. The presence of other domestic animals around the house, like free-chickens and horses, also ensures the availability of food sources for sandflies, contributing to the increase in population density in the home environment, which favors the chain of transmission of VL [24]. The prevalence of CVL obtained in this study suggests that this parasitosis is widely distributed in the Natal, featuring the region as endemic area, due to the large number of canine cases of the disease, indicating into serious public health problem. Necessarily, other factors must be involved, especially the potential for transmission due to the vector density and infection rate of vectors, and the vulnerability of susceptible people to disease development. In Natal, the serological surveys among the population of dogs and entomological surveys, in endemic areas, show very high prevalence of CVL in some places and the abundant and predominant vector presence; which lead to high risk of transmission to humans. In this study, females were found to be the most affected, although no significant difference was observed regarding gender. These data corroborate the studies of França-Silva et al. [17], Matos et al. [25] and Mohebali et al [19], which reported no sexual predisposition for the disease. According to Naveda et al. [26], the gender is not a predisposing factor for infection in dogs. However, Garcia et al. [27] showed a high infection predominance in male in their studies. Alencar \& Cunha [28] in Ceará state, showed a growing trend of dog leishmaniasis infection mainly of male.

The mongrel dogs were found to be the most affected, with a frequency of $78.2 \%$ of dogs with CVL. However, this was not significantly different from the breeds. The highest prevalence of infection in mongrel dogs may be explained by the study has occurred in remote areas and low socioeconomic development, where the mongrel dogs are most prevalent. Factors associated with social status and poor housing conditions of the population have contributed enormously to the urbanization of VL. Corroborating these results, Gontijo and Melo [29], in studies of risk factors for canine VL in Brazil, have so far presented no evidence of infection related to the breed. There was no statistically significant difference regarding the relationship between leishmaniasis infection and clinical signs of disease, where $95 \%$ of infected animals showed no specific clinical signs, supporting by study of Cardoso et al. [20] and Guimarães et al. [30]. The clinical manifestations observed in seropositive dogs, such as skin changes, lymphadenopathy, splenomegaly, onychogryphosis and eye diseases, are similar to those observed in other studies $[16,31]$. The skin changes are the clinical signs most commonly observed in canine visceral leishmaniasis [32]. This characteristic was observed in this study, where all dogs with clinical manifestations of the disease showed some skin change, such as alopecia, scaling and ulceration of ear tip. High parasite load in the skin of dogs has led to the development of several surveys of this reservoir, since many of these animals do not develop clinicaly or do so late [14]. The presence of $50-70 \%$ of asymptomatic dogs in endemic areas, potentially infective for the vector, denotes the importance of canines for serological surveys anticipating that the prophylactic measures, as the canine cases precede the disease in man [33].

The results suggest that the CVL is widely distributed in the city, characterizing the region as an important endemic area, due to a large number of canine and human cases of the disease, indicating a serious public health problem, emphasizing the need for epidemiological studies which outlines the canine disease where visceral leishmaniasis is endemic, although associated prevalence of infection and related factors as breed, gender and presence of symptoms were not observed.

The dynamics of the spread of VL is closely linked to transmission of Leishmania infection among wild dogs to domestic dogs on the urban peripheries. However, this pattern does not exclude transmission under better socioeconomic conditions in central areas of cities [34]. Thus, the visceral leishmaniasis control also involves community education in risk areas, teaching measures to avoid production areas that favor the development of phlebotomine sand flies in backyards and schools. It is possible that infected wild canids may serve as reservoirs for transmission of CVL in dogs in peri-urban areas while maintaining the dynamics of transmission to humans living in marginalized areas, poor socioeconomic conditions with limited public services. However, the centralization of epidemiological surveillance and visceral leishmaniasis control activities to the municipalities could be an additional complicating factor, due to deficiencies in infrastructure at the local level for dealing with the problem's complexity.

\section{CONFLICT OF INTEREST}

The authors confirm that this article content has no conflict of interest.

\section{ACKNOWLEDGEMENTS}

We thank the technicians of the Zoonosis Control Center of Natal and Notifiable Diseases Division of The Municipal Health Secretary for the availability of data.

This work was supported by grants from $\mathrm{CNPq}$ (575840/2008-0 and 301837/2012-0)

\section{ETHICAL APROVAL}

This study was reviewed and approved by the ethical committee of Federal University of Rio Grande do Norte.

\section{REFERENCES}

[1] Ministério da Saúde (MS). Secretaria de Vigilância à saúde. Manual de vigilância e controle da Leishmaniose visceral. $1^{\text {st }}$ ed. Brasília: Ministério da Saúde, 2006.

[2] Maia-Elkyhoury ANS, Alves WA, Sousa-Gomes ML, et al. Visceral leishmaniasis in Brazil: trends and challenges. Cad Saúde Públ 2008; 24: 2941-7.

[3] Werneck GL. Geographic spread of visceral leishmaniasis in Brazil. Cad Saúde Públ 2010; 26: 644-5. 
[4] Ministério da Saúde (MS). Sistema de Informação de Agravos de Notificação. Brasília, 2013. Availabe from http://www2.datasus.gov.br 2013

[5] Lainson R, Rangel EF. Lutzomyia longipalpis and the ecoepidemiology of American visceral leishmaniasis, with particular reference to Brazil: a review. Mem Inst Oswaldo Cruz 2005; 100: 811-27.

[6] Alvar J, Cañavate C, Molina R, Moreno M, Nieto J. Canine Leishmaniasis. Adv Parasitol 2004; 57: 1-88.

[7] Alves W. Controle da Leishmaniose visceral baseado no reservatório canino. In: Informe final de la reunion de expertos OPS/OMS sobre Leishmaniasis em las Américas. Rio de Janeiro: OPAS 2006, pp. 94-8.

[8] Moreno J, Alvar J. Canine leishmaniasis: epidemiological risk and the experimental model. Trends Parasitol 2002; 18: 399-405.

[9] Nascimento ELT, Martins DR, Monteiro GR, et al. Forum: geographic spread and urbanization of visceral leishmaniasis in Brazil. Postscript: new challenges in the epidemiology of Leishmania chagasi infection. Cad Saúde Públ 2008; 24: 2964-7.

[10] Instituto Brasileiro de Geografia e Estatística (IBGE). Censo 2010. Available from http://www.censo2010.ibge.gov.br/agsn2/2010

[11] Empresa Agropecuária do Estado do Rio Grande do Norte (EMPARN). Available from http://www.emparn.rn.gov.br 2013

[12] Amóra SSA, Santos MJP, Saraiva JCR, et al. Detecção de anticorpos anti-Leishmania chagasi em cães da área rural do município de Mossoró, Rio Grande do Norte. Ciênc Anim Bras 2004; 5: 166-8.

[13] Torres FD, Brandão Filho SP. Soroprevalência da leishmaniose visceral canina no Município de Paulista, Pernambuco, Brasil. Anclivepa Brasil 2005 3: 343-4.

[14] Silva AVM, De Paula AA, Cabrera MAA, Carreira JCA. Leishmaniasis in domestic dogs: epidemiological aspects. Cad Saú Públ 2005; 21: 324-8.

[15] Cardoso L, Schallig HDFH, Neto F, et al. Serological survey of Leishmania infection in dogs from the municipality of Peso da Régua (Alto Douro, Portugal) using the direct agglutination test (DAT) and fast agglutination screening test (FAST). Acta Trop 2004b; 91: 95-100.

[16] Rondon FCM, Bevilaqua CML, Franke CR, et al. Crosssectional serological study of canine Leishmania infection in Fortaleza, Ceará state, Brazil. Vet Parasitol 2008; 155: 24-31.

[17] França-Silva JC, Costa RT, Siqueira AM, et al. Epidemiology of canine visceral leishmaniasis in the endemic área of Montes Claros Municipality, Minas Gerais state, Brazil. Vet Parasitol 2003; 111: 161-73.

[18] Michalsky EM, Rocha MF, Lima ACVMR, et al. Infectivity of seropositive dogs, showing different clinical forms of leishmaniasis, to Lutzomyia longipalpis phlebotomine sand flies. Vet Parasitol 2007; 129: 243-51.
[19] Mohebali M, Hajjaran H, Hamzavi Y, et al. Epidemiological aspects of canine visceral leishmaniosis in the Islamic Republic of Iran. Vet Parasitol 2007; 147: 67-76.

[20] Cardoso L, Rodrigues M, Santos H, et al. Sero-epidemiological study of canine Leishmania spp. infection in the municipality of Alijó (Alto Douro, Portugal). Vet Parasitol 2004a; 121: 21-32.

[21] Vieira JBF, Coelho GE. Leishmaniose visceral ou calazar: Aspectos epidemiológicos e de controle. Rev Soc Bras Med Tropical 1998; 31: 85-92.

[22] Passos VM, Falcão AL, Marzochi MCA, et al. Epidemiological aspects of american cutaneous leishmaniasis in a periurban area of the metropolitan region of Belo Horizonte, Minas Gerais, Brazil. Mem Inst Oswaldo Cruz 1993; 88: 103-10.

[23] Cabrera MAA, Paula AA, Camacho LAB, et al. Canine visceral leishmaniasis in Barra de Guaratiba, Rio de Janeiro, Brazil: assessment of risk factors. Rev Inst Med Trop S Paulo 2003; 45: 79-83.

[24] Wijeyratne PM, Arsenault LKJ, Murphy CJ. Endemic diasease and development: the leishmaniases. Acta Trop 1994; 56: 349-64.

[25] Matos MM, Filgueira KD, Amora SSA, et al. Ocorrência da Leishmaniose Visceral em Cães em Mossoró, Rio Grande do Norte. Ciênc Anim 2006; 16: 51-4.

[26] Naveda LAB, Moreira EC, Machado JG, et al. Aspectos epidemiológicos da leishmaniose visceral canina no município de Pedro Leopoldo, Minas Gerais, 2003. Arq Bras Med Vet Zootec 2006; 58: 988-93.

[27] Garcia AM, Rebelo JMM, Caldas A, et al. Natural history of the infection caused by Leishmania chagasi in domestic dogs (Canis familiaris) in endemic area of São Luis Island - Maranhão, Brazil. Gaz Méd Bahia 2009; 79:147-55.

[28] Alencar JE, Cunha RV. Inquéritos sobre calazar canino no Ceará Novos resultados. Rev Bras Malariol Doenças Trop 1963; 36: 391404.

[29] Gontijo CMF, Melo MN. Leishmaniose visceral no Brasil: quadro atual, desafios e perspectivas. Rev Bras Epidemiol 2004; 7: 338-49.

[30] Guimarães KS, Batista ZS, Dias EL, et al. Canine visceral leishmaniasis in São José de Ribamar, Maranhão State, Brazil. Vet Parasitol 2005; 131: 305-9.

[31] Silva ES, Gontijo CMF, Pacheco RS, et al. Visceral leishmaniasis in the metropolitan region of Belo Horizonte, State of Minas Gerais, Brazil. Mem Inst Oswaldo Cruz 2001; 96: 285-91.

[32] Gállego M. Zoonosis emergentes por patógenos parasitos: las leishmanioses. Rev Off Int Epizoot 2004; 23: 661-76.

[33] Oliveira CDL, Assunção RM, Reis IA, Proietti FA. Spatial distribution of human and canine visceral leishmaniasis in Belo Horizonte, Minas Gerais State, Brasil, 1994-1997. Cad Saú Públ 2001; 17: 1231-3.

[34] Harhay MO, Olliaro PL, Costa DL, et al. Urban parasitology: visceral leishmaniasis in Brazil. Trends Parasitol 2011; 27: 403-9.

Received: December 19, 2014

Revised: January 25, 2015

Accepted: January 25, 2015

(C) Barbosa et al.; Licensee Bentham Open.

This is an open access article licensed under the terms of the Creative Commons Attribution Non-Commercial License (http://creativecommons.org/licenses/by-nc/3.0/) which permits unrestricted, non-commercial use, distribution and reproduction in any medium, provided the work is properly cited. 